\title{
Examining Effect of Participating to Recreational Activities on Loneliness Level of Middle School Students
}

\author{
Nurullah Emir Ekinci \\ School of Physical Education and Sport, Dumlupınar University, Turkey
}

Copyright $\mathrm{C} 2018$ by authors, all rights reserved. Authors agree that this article remains permanently open access under the terms of the Creative Commons Attribution License 4.0 International License

\begin{abstract}
The present study aimed to investigate middle school students' loneliness level according to participating in recreation activities, the way of participation in recreation activities, and the gender and marital status of the parents. The study sample consisted of voluntarily participated 330 students (184 females and 146 males). The easy sampling method preferred in the present study. The face-to-face survey method was used to collect the data. In the study 'UCLA Loneliness Scale' developed by Russell et al. [7] and adapted to Turkish by Demir [2] and a questionnaire form consisting of 4 questions developed by the researcher are used as data gathering tool. The data obtained for the research were first transferred to the computer and then analyzed by the SPSS program. The error margin level in the study was taken as $p<0.05$. The Cronbach alpha of the study was found to be 0.80 . As a result, there were not any significant differences between loneliness level of participant and their gender $(\mathrm{p}>0.05)$. But between the participant's loneliness level and participating in recreation activities, the way of participation in recreation activities and the marital status of the parents, there were statistically significant results $(\mathrm{p}<0.05)$.
\end{abstract}

Keywords Recreation, Sport, Loneliness, Students

\section{Introduction}

Loneliness in childhood and adolescence has received considerable empirical attention over the past two decades [11]. Feeling lonely is a sad but relatively common experience for children in school-age children [21]. When loneliness becomes a frequently occurring phenomenon, there are serious implications for emotional and physical well-being [3]. Schools are obliged not only to provide information but also to socialize the individual. In this respect, leisure education is given importance by education institutions regarding evaluation of non-school hours of students. Where leisure education is not emphasized, individuals face various obstacles and use time inefficiently [5]. Loneliness is a multidimensional concept with different meanings under different causes and conditions [19]. Loneliness is defined by different authors in different ways. Some writers see it as a situation with objective conditions, others as completely subjective, and some as existential. The common feature of all of them is that the concept of loneliness is a painful emotional state [12]. Several definitions of loneliness are given by some authors as follows: According to Peplau and Perlman, loneliness is a mental state [4], which is the result of perceiving the difference between an individual's existing social relationship and the desired social relationship; according to Duyan et al. [24], a process that exists for all mankind and will exist in the future; according to Davis [3], it is an experience that is unpleasant but common among children, young people and adults; according to Demir and Tarhan [1], it is a common phenomenon especially in adolescence because puberty is an important and developmental process; according to Kızar [20], facing with a negative situation; Rook [9], defines it as an ever-increasing feeling when one is rejected by others, is misunderstood, and has no suitable friends or partners to perform the desired activities. It is known that recreation activities have an important place in solving loneliness and these activities provide positive contributions not only to the feeling of loneliness of the individual but also to the physical, social and emotional development. These activities make talents such as creativity and leadership functional, and they develop personality characteristics such as aggression, determination, harmony, productive, decisive, mutual respect and understanding, adherence to rules, cooperation, independence, self-discipline, and diligence [15]. It is clear that a healthy society consists of physically and psychologically healthy individuals [18].

In this respect, the increase of the relations between the individuals by using the integrating and socializing feature of the sport shows that the social structure is a necessity for the participation of the individual in sportive and 
recreational activities and the completion of the adolescence period in which the personality structure starts to sit in a physically and socially healthy manner [5]. That is why our motivation in this study was to investigate the effect of gender, participating recreation activities, the way of participation to recreation activities and marital status of the parents on loneliness level of middle school students to see the positive and negative effect of variables.

\section{Materials and Methods}

This section includes the model of the group, the data collection tool, analyses, methods and techniques related to the solution of the data.

\subsection{Research Model}

The research was based on a quantitative research design and descriptive cross-sectional study. A general screening model was applied to arrive at a general judgment about the universe, in which the whole universe or a sample taken from it was scanned [17].

\subsection{Research Sample}

The research sample consisted of a total of 365 randomly chosen middle school students from Fatih and Dumlupınar middle schools in the Kütahya city center voluntarily participated in the study. The 35 scales thought to be missing or inaccurate were not evaluated. Finally, a total of 330 ages ranged from 10 to 14 years old $(12.56 \pm 1.49)$ middle school students comprised of 146 males and 184 females were selected by the purposive sampling method.

\subsection{Data Collection Tool}

In addition to the "Demographic Information Form" which questioned the demographic characteristics of the students in the research, "UCLA Loneliness Scale" was used. UCLA Loneliness Scale: consists of 20 items (11 positives and 9 negatives), describing the subjective feeling of loneliness, none of which refers specifically to loneliness. Consequently, the scale does not directly measure states that laypeople attribute as loneliness, but rather the scale measures a theoretically defined and scientifically validated understanding of loneliness. The 20 items are rated on a 4-point Likert scale following the rate of frequency, ranging from never (1) to always (4). Scores on the scale range from 20 to 80 with higher scores reflecting greater loneliness [7]. The study of the validity and reliability of the scale in our country was carried out by Demir [2]. The internal consistency factor of the Turkish version of the scale is .96 , and test-retest reliability is .94 . Scale 1, 5, 6, 9, 10, 12, 15, 16, 19 and 20 are reverse coded.

\subsection{Analysis of Data}

For the data obtained in the study, the SPSS package program was used, and frequency (f) and percent (\%) distributions of the variables were calculated. The histograms, Skewness, and Kurtosis values were checked to ensure the normal distribution of the data. The Skewness and Kurtosis were considered to be valued -2 to +2 [6]. Therefore, the t-test and ANOVA test were used. Significance set at $\mathrm{p}<0.05$ and results were considered significant with $95 \%$ confidence interval.

\section{Findings}

Table 1. Demographic distribution of participants

\begin{tabular}{|c|c|c|c|}
\hline \multicolumn{2}{|c|}{ Variable } & $\mathrm{f}$ & $\%$ \\
\hline \multirow{3}{*}{ Gender } & Female & 184 & 55,8 \\
\hline & Male & 146 & 44,2 \\
\hline & Total & 330 & 100,0 \\
\hline \multirow{5}{*}{$\begin{array}{c}\text { The way of participation to } \\
\text { recreation activities }\end{array}$} & Usually alone & 44 & 13,3 \\
\hline & Usually with family & 53 & 16,1 \\
\hline & Usually with friends & 189 & 57,3 \\
\hline & $\begin{array}{c}\text { With guidence of an } \\
\text { expert }\end{array}$ & 44 & 13,3 \\
\hline & Total & 330 & 100,0 \\
\hline \multirow{3}{*}{$\begin{array}{c}\text { Participating to recreation } \\
\text { activities }\end{array}$} & Yes & 190 & 57,7 \\
\hline & No & 140 & 42,3 \\
\hline & Toplam & 330 & 100,0 \\
\hline \multirow{3}{*}{ Marital status of the parents } & Together & 49 & 14,8 \\
\hline & Separate & 281 & 85,2 \\
\hline & Total & 330 & 100,0 \\
\hline
\end{tabular}

Table 2. T-test result according to gender

\begin{tabular}{|c|c|c|c|c|c|c|}
\hline \multicolumn{2}{|c|}{} & $\mathrm{n}$ & $\overline{\mathrm{x}}$ & $\mathrm{sd}$ & $\mathrm{t}$ & $\mathrm{p}$ \\
\hline \multirow{3}{*}{ Loneliness } & Female & 184 & 50,9 & 6,86 & \multirow{2}{*}{1,37} & \multirow{2}{*}{, $17^{*}$} \\
\cline { 2 - 8 } & Male & 146 & 49,9 & 6,73 & & \\
\hline
\end{tabular}

$* \mathrm{p}>0,05 ; * * \mathrm{p}<0,01$

Table 2 shows the $t$ test analyses results of participants' gender differences. According to this result, there is no any significant difference on loneliness level of female and male students $(\mathrm{p}>0,05)$.

Table 3. T-test result according to marital status of the parents

\begin{tabular}{|c|c|c|c|c|c|c|}
\hline \multicolumn{2}{|c|}{} & $\mathrm{n}$ & $\overline{\mathrm{x}}$ & $\mathrm{sd}$ & $\mathrm{t}$ & $\mathrm{p}$ \\
\hline \multirow{2}{*}{ Loneliness } & Together & 49 & 48,6 & 7,55 & \multirow{2}{*}{$-2,09$} & \multirow{2}{*}{$03^{*}$} \\
\cline { 2 - 6 } & Separate & 281 & 50,8 & 6,64 & & \\
\hline
\end{tabular}

${ }^{*} \mathrm{p}<0,05 ; * * \mathrm{p}<0,01$ 
Table 3 shows the $t$ test analyses results of parents' marital status. According to this result, marital status of the parents' has a significant effect on loneliness level of students $(\mathrm{p}<0,05)$. It is seen that students whose parents are living together $(\bar{x}=48,6)$ feel less loneliness than the students whose parents are separate $(\overline{\mathrm{x}}=50,8)$.

Table 4. T-test result according to participating recreational activities

\begin{tabular}{|c|c|c|c|c|c|c|}
\hline \multicolumn{2}{|c|}{} & $\mathrm{n}$ & $\overline{\mathrm{x}}$ & $\mathrm{sd}$ & $\mathrm{t}$ & $\mathrm{p}$ \\
\hline \multirow{2}{*}{ Loneliness } & Yes & 190 & 49,7 & 7,16 & \multirow{2}{*}{$-2,47$} & \multirow{2}{*}{, $01^{*}$} \\
\cline { 2 - 6 } & No & 140 & 51,5 & 6,18 & & \\
\hline
\end{tabular}

${ }^{*} \mathrm{p}<0,05 ; * * \mathrm{p}<0,01$

Table 4 shows the $t$ test analyses results of participating to the recreational activities. According to this result, recreational activities has a significant effect on loneliness level of students $(\mathrm{p}<0,05)$. It is seen that students who participate recreational activities $(\bar{x}=49,7)$ feel less loneliness than the students who doesn't $(\overline{\mathrm{x}}=51,5)$.

Table 5. ANOVA test result according to the way of participating to the recreation activities

\begin{tabular}{|c|c|c|c|c|c|c|c|}
\hline & & $\mathrm{n}$ & $\overline{\mathrm{x}}$ & $\mathrm{sd}$ & $\mathrm{f}$ & $\mathrm{p}$ & Tukey \\
\hline \multirow{5}{*}{ Loneliness } & Usually alone & 106 & 48,6 & 7,08 & \multirow{5}{*}{2,88} & \multirow{5}{*}{, 023} & \multirow{5}{*}{$1,2-3$} \\
\hline & \begin{tabular}{|c|}
$\begin{array}{c}\text { Usually with } \\
\text { family }\end{array}$ \\
\end{tabular} & 60 & 53,1 & 6,83 & & & \\
\hline & $\begin{array}{c}\text { Usually with } \\
\text { friends }\end{array}$ & 73 & 51,3 & 6,40 & & & \\
\hline & \begin{tabular}{|c|}
$\begin{array}{c}\text { With guidence } \\
\text { of an expert }\end{array}$ \\
\end{tabular} & 91 & 50,4 & 6,13 & & & \\
\hline & Total & 330 & 50,5 & 6,81 & & & \\
\hline
\end{tabular}

${ }^{*} \mathrm{p}<0,05 ; * * \mathrm{p}<0,01$

Table 5 shows the ANOVA analyses results according to the way of participating to the recreation activities. According to this result, recreational activities has a significant effect on loneliness level of students $(p<0,05)$. Tukey test was applied to see the differences between groups. According to result, the difference was observed between students who attend in recreational activities usually alone and students who participate with family and friends $(\mathrm{p}<0,05)$.

\section{Discussion and Conclusions}

In this section, the results of the loneliness levels of the students at the middle school level are examined and interpreted.

The t-test was used to find the effect of gender on loneliness. Findings demonstrated that statistically no significant difference is found between the gender change and loneliness levels of the students participating in the research $(p>0,05)$. This result is parallel to some studies in the literature. According to Cassidy and Asher [9], no statistically significant difference is found between loneliness and gender in children and adolescents. Also according to Ekinci et al. [16], no statistically significant difference is found between gender and loneliness of high school students. But, according to the studies of Yilmaz et al. [8] and Eskin [14], the level of loneliness among secondary school students is found to vary according to gender. Future research should aim to provide a deeper understanding of the differential effect of gender on loneliness level of middle school students.

The t-test was used to find out whether the level of the loneliness of the participants varied according to the marital status of the parents. Statistically, a significant result was found $(\mathrm{p}<0.05)$. Results show that students whose parents are living together feel less loneliness than the students whose parents are separate. This result is parallel to the study of Körler [25]. According to the study of Körler the loneliness level of students whose parents are living together is less than students whose parents are living separately.

The t-test was used to find out the effect of recreational activities on loneliness. Findings demonstrated that statistically, a significant difference was found between the participating in the recreational activities and loneliness level of the students $(p<0,05)$. There are two possible explanations for this expected result. First, recreational activities help students to become more social [10]. Second, above and beyond an individual's response to loneliness, students' awareness of their acceptance by peers in various contexts should be considered.

ANOVA test was used to find out the effect of the way of participating in the recreational activities. Findings demonstrated that statistically, a significant difference was found between the way of participating in the recreational activities and loneliness level of the students $(\mathrm{p}<0.05)$. The difference was observed between students who attend in recreational activities usually alone and students who participate with family and friends. According to Heredia et al. [10], students those with high levels of peer support had low levels of loneliness than students with low levels of peer support. We may say that having good peer and family relationships is better for low level of loneliness. This finding is consistent with research suggesting that peer support is an important contributor to wellbeing for middle school students [11]. Study of Boivin and Hymel [13] support this result. According to Boivin and Hymel, being more socially withdrawn is associated with loneliness in elementary school. Also similar result can be found in the study of Woodhouse et al. [23]. According to Woodhouse et al, "when peer relations go well for adolescents, adolescents are less likely to be lonely".

\subsection{Limitations and Suggestions}

The present study has a number of limitations. This study is limited with middle school students who study regularly at the city center of the Kütahya. Loneliness in children is a relatively new research topic. It can show as 
an obstacle for a more comprehensive study that there are not enough studies which relate to recreation and loneliness and the researchers exist are mostly studied for adults. Therefore, it is thought that studies in this area should be increased. Also, further studies may focus on larger example groups. Family economic conditions also can be an important factor to control for further studies, and it will be an excellent factor to check. As suggested in this study, factors such as peer support and family support are important predictors of loneliness for middle school students who are lonely. Also school counselors, administrators and parents can use the results of this study to protect students from negative effect of loneliness.

\section{REFERENCES}

[1] A. Demir, N. Tarhan. Loneliness and social dissatisfaction in Turkish adolescents. The Journal of Psychology, 135(1): 113-123, 2001.

[2] A. Demir. UCLA Yalnızlık Ölçeğinin Geçerlik ve Güvenirliği, Psikoloji Dergisi, 7, 8, 14-18, 1989.

[3] B. D. Davis. Loneliness in children and adolescents. Issues in Comprehensive Pediatric Nursing, 13(1), 59-69, 2009, doi: 10.3109/01460869009009745.

[4] B. S. Fees, P. Martin, L. W. Poon. A model of loneliness in older adults. The Journals of Gerontology Series B: Psychological Sciences and Social Sciences, 54(4), P231-P239, 1999.

[5] C. Ayhan, N.E. Ekinci, İ. Yalçın, Ş. Yiğit. Investigation of Constraints that Occur during Participation in Leisure Activities by High School Students: A Sample of Turkey, Educ. Sci. 8, 86, 2018, doi:10.3390/educsci8020086

[6] D. George, M.P. Mallery. Using SPSS for Windows Step by Step: A Simple Guide and Reference, 4th ed.; Allyn \& Bacon: Boston, MA, USA, 2002; ISBN 0205375529.

[7] D. Russell, L. A. Peplau, C. E. Cutrona. The revised UCLA Loneliness Scale: Concurrent and discriminant validity evidence. Journal of personality and social psychology, 39(3): 472, 1980.

[8] E. Yılmaz, E. Yılmaz, F. Karaca. Üniversite öğrencilerinin sosyal destek ve yalnızlık düzeylerinin incelenmesi. Genel Tip Dergisi, 18(2), 2008.

[9] J. Cassidy, S. R. Asher. Loneliness and peer relations in young children, Child Development, 63(2), 350-365, 1992.

[10] J. D. Heredia, M. L. Sanchéz Gonzalez, C. M. Rosner, X. He, L. G. Castillo, L. Ojeda. The Influence of Loneliness and Interpersonal Relations on Latina/o Middle School Students' Wellbeing. Journal of Latinos and Education, 16(4), 338-348, 2017.

[11] K. J. Rotenberg. Parental antecedents of children's loneliness. In K. J. Rotenberg, \& S. Hymel (Eds.),
Loneliness in childhood and adolescence (pp. 176-200), New York: Cambridge University Press, 1999.

[12] K. S. Rook. Parallels in the study of social support and social strain. Journal of Social and Clinical Psychology, 9(1), 118-132, 1990.

[13] M. Boivin, S. Hymel. Peer experiences and social self-perceptions: A sequential model. Developmental Psychology, 33, 135-145, 1997.

[14] M. Eskin. Ergenlikte Yalnızlık, başetme yöntemleri ve yalnızlığın intihar Davranışı ile ilişkisi, Klinik Psikiyatri, 4, $5-11,2001$.

[15] N. Akgün. Egzersiz Fizyolojisi, Ege Üniversitesi BESYO Yayınları, İzmir, 1986.

[16] N. E. Ekinci, M. Demirel, D. H. Demirel, U. Işık. Lise öğrencilerinin yalnızlık algılarının rekreasyonel etkinliklere katılımları ve bireysel değişkenlere göre incelenmesi. Sportif Bakış: Spor ve Eğitim Bilimleri Dergisi, 2(2), 71-78, 2015.

[17] N. Karasar. Bilimsel Araștırma Yöntemi, 28th ed.; Nobel Academic Publication: Ankara, Turkey, 2015; ISBN 6055426583 .

[18] N. Özdemir. Düzenli Fiziksel Aktivitenin İlköğretim Öğrencilerinin Okula Yabancılaşma ve Yalnizlik Düzeyleri Üzerine Etkileri, Ege Üniversitesi, Beden Eğitimi ve Spor Sporda Psiko-Sosyal Alanlar Anabilim Dalı, İzmir, 2011.

[19] Ö. Arslan. TV Dizilerinde yer alan karekterler ile kurulan parasosyal etkileşim: bağlanma biçimleri ve yalnızlık açısından bir inceleme, Ankara Üniversitesi Sosyal Bilimler Enstitüsü Psikoloji (Sosyal Psikoloji) Anabilim Dalı, Ankara s40-41, 2013.

[20] O. Kızar. Farklı Branşlardaki Görme Engelli Sporcuların Yalnızlık Düzeylerinin Karşılaştırılması, Fırat Üniversitesi, Sağlık Bilimleri Enstitüsü Beden Eğitimi ve Spor Anabilim Dalı, Elazığ, 2012.

[21] P. Qualter. Loneliness in children and adolescents: What do schools and teachers need to know and how can they help? Pastoral Care in Education, 21(2), 10-18, 2003.

[22] R. Buchanan, G. L. Bowen. In the context of adult support: The influence of peer support on the psychological well-being of middle-school students. Child \& Adolescent Social Work Journal, 25(5), 397-407, 2008, doi:10.1007/s10560-008-0143

[23] S. S. Woodhouse, M. J. Dykas, J. Cassidy. Loneliness and peer relations in adolescence. Social development, 21(2), 273-293, 2012.

[24] V. Duyan, G. Ç. Duyan, E. G. Çifti, Ç. Sevin, E. Erbay, M. İkizoğlu. Lisede okuyan öğrencilerin yalnızlık durumlarına etki eden değişkenlerin incelenmesi, Eğitim ve Bilim, 33(150), 2010.

[25] Y. Körler. İlköğretim ikinci kademe öğrencilerinin çeșitli değişkenler açısından yalnızlık düzeyleri ve yalnızlık ile sosyal duygusal öğrenme becerileri arasındaki ilişkiler, Anadolu Üniversitesi Rehberlik ve Psikolojik Danışmanlık Anabilim Dalı, Yüksek lisans tezi, Eskişehir, 2011.. 